\title{
Children's Functioning in Difficult Situations in the Contemporary World
}

\author{
Małgorzata Cywińska \\ Prof. Dr., Faculty of Educational Studies \\ Adam Mickiewic \\ University, Poznań, Poland
}

\section{Abstract}

Stress is an integral part of our lives. It also applies to our childhood. That is why it is so important to know how children cope with stress (how they learn coping strategies) and to equip them with the competences to cope constructively with stressful situations throughout life. This article describes strategies for coping with stress that are characteristic for children at the end of early school education. They have been identified in the course of my own research aimed at characterizing child stress and relate to a fragment of research activities aimed at 8- and 9-year-old children. The research established that in some children the developmental process of coping with stress has started: children look for, investigate, and think how to cope with difficulties. In this struggle, however, they focus on people who could be a source of support for them in coping with stressful situations. Among children's stress coping strategies, an important role is also played by emotionally focused strategies, which are aimed at reducing negative emotions and arousing positive emotions. Contemporary times show how important it is to develop, from the earliest period of an individual's life, competences in dealing with difficult situations, with stressful situations. Development of emotional intelligence, including emotional self-awareness, self-regulation, empathy, creative problem solving, the ability to establish and maintain relationships, including friendship relationships, the development of specific cognitive skills (divergent thinking, cognitive decentration), as well as psychological resilience are the basis of constructive coping with these situations. The family environment, a stable, harmoniously functioning home, as well as educational influence of preschool and early school environment play an enormous role in shaping these competences in children.

Keywords: stress, resistance to stress, children's physiological and behavioural reactions to stress, problem focused coping strategies, emotionally focused coping strategies, coping strategies for children in early school age 


\section{Introduction}

In recent years the number of factors causing stress in children has increased as a result of the modern lifestyle implied by social and economic transformations requiring constant adaptation to changing conditions, and the increase in negative phenomena such as greater social poverty, unemployment, alcoholism, increasing number of divorces, family conflicts, long absence of one parent due to their work abroad, loneliness, aggression and preoccupation with success. Georgia Witkin has shown on the basis of her own research that childhood is a period full of strong tensions. The author conducted "Childhood stress test" and identified groups of factors causing stress in children's life (Witkin 2000, 25 -26). These include, among others:

factors coming from the school environment, which are connected with grades, homework, tests and promotion to the next class;

factors coming from the family environment that reflect children's concern for their family, their parents' health;

factors related to peer environment such as the lack of acceptance, mockery, ridicule, backbiting, slander, teasing, and disloyal and false friends;

factors related to the news coming from the surrounding world concerning bombings, nuclear disasters, environmental pollution or wars.

Moreover, Georgia Witkin's research indicates that adults have insufficient knowledge about child stress and are not always aware of it. The author showed that:

"Parents do not know how often their children worry.

Parents are not aware of how many children feel lonely.

Parents have no idea how often insomnia of their children is caused by stress.

Parents have no idea how often their children are afraid to talk to them.

Parents underestimate the stress generated by school and overestimate the importance of peer pressure.

Parents do not realize how often children's fears are realistic" (Witkin 2000, 21 -22).

Children have their own specific stress language, which we should be able to read correctly. They speak to us through their behaviour, their emotions and body language. The physical reactions of children to stress, identified by Georgia Witkin's research, are: insomnia, stomach pains, nausea, and headaches (Witkin 2000, 28 30).The above empirical data are confirmed by my own research on the topic in question. In the course of my research I have shown that children in stressful situations feel headaches, have problems with sleeping, stomach aches, and nausea. However, among the behavioural symptoms of child stress, I found the following reactions in children: gloomy mood, avoiding companionship - desire for loneliness, 
running away into dreams, getting into conflicts with siblings, getting into conflicts with peers (Cywińska 2017, 208- 225).

Therefore, the ability of parents, teachers, and educators to recognize children's stressful situations and to notice the above mentioned physiological and behavioural reactions, combining these reactions with their difficult situations in them becomes extremely important. It is therefore invaluable to help children to develop their stress coping skills, to be aware of their strategies for coping with stress and, if necessary, to be constructive in directing their actions in this area. It is important that the stress protection system they have developed during childhood can be applied effectively throughout their lives.

\section{Stress and resistance to stress}

The term "stress", as it is currently used, was coined by Hans Selye, a Canadian researcher and physiologist, who defined biological stress as "the non-specific response of the body to any demand for change" (Selye 1977, 25). Unspecific changes in the functioning of the human body (nausea, headaches, stomach aches, insomnia, and loss of appetite) arise when the human body is subject to the influence of a stressor (stress-inducing factor). Because they occur in connection with changes in psychological regulatory mechanisms such as cognitive processes, emotions or motivation, psychological stress, which is sometimes treated differently, is also distinguished.

Psychological stress is identified:

with the internal state of the body meaning negative emotional tension (e.g. I.L. Janis' theory of emotional tension). According to Irving L. Janis, a stress situation in an average person causes a high degree of emotional tension, which interferes with the normal way of reaction;

with external factors disturbing proper functioning, i.e. referring to the characteristics of the environment in which stimuli considered harmful or threatening appear (e.g. Tadeusz Tomaszewski's theory of difficult situations or Maria Tyszkowa's developmental theory of difficult situations);

with a type of relationship between an individual and his or her environment (e.g. transactional stress theory by Richard S. Lazarus and Susan Folkman). According to this approach, stress is a result of human cognitive processes, i.e. it depends on how a person assesses and understands his/her relationship with the environment. It is therefore "a special kind of relationship between man and his environment, which is assessed by man as being taxing or exceeding his resources and endangering his wellbeing" (Terelak 2001, 70).

Stress is part of our lives. Hans Selye shows that we should not always avoid it. Apart from destructive stress, which disorganizes our lives and destroys people and is a reaction to threats and fears, we can also cope with eustress, i.e. good stress, which 
contains pleasant experiences of joy, fulfilment and self-expression, caused by stressors motivating people to make efforts and shape our life achievements.

It is also worth emphasizing that every person has a different "resistance to stress". It is treated either as a lack of emotional response to a difficult situation (e.g. lack of such emotional states as anxiety, fear, anger, etc.) or as the ability to maintain the previous direction, efficiency and level of organisation of behaviour despite the occurrence of stress. The ability to think and act rationally despite the stressor serves here as an indicator of resistance understood in this way.

Resistance to stress is determined by various biological and psychological factors. These include:

the tasks that a person performs (when performing known, trained tasks, people show more resistance than with other, less known tasks);

physiological processes and psychological changes that occur independently of the stress situation (e.g. illness, fatigue lowers stress tolerance);

constant characteristics of the individual determining his or her style of reaction (features of the nervous system, childhood experiences, self-esteem, features of emotional reaction, way of perceiving reality) (Frączek 1978, 670 - 678).

The above factors suggest that resistance to stress can be modified and practiced - it can be strengthened during an individual's life, which is confirmed by research conducted by, among others: Seymour Epstein, Neal E. Miller, Janusz Reykowski, and Irena Heszen.

\section{Methodology}

The empirical research presented in this text is part of a study on stressful situations of children leaving early school education - children attending the third grade of primary school (8- and 9-year-old). The research aimed at characterizing various aspects of child stress was based on the accounts of 280 children and the opinions of their mothers (280) and 100 teachers of early school education. The research was conducted on the basis of questionnaires and individual interviews, whereas the results were discussed in detail in the following publication: Cywińska, M. (2017). Stres dzieci w młodszym wieku szkolnym. Objawy, przyczyny, możliwości przeciwdziałania, Poznań. The present paper presents various kinds of strategies which children use to cope with stressful situations, releasing negative emotions.

\section{Coping in stressful situations}

In the face of stressful situations it becomes extremely important to cope with them. Coping with stress is conditioned by a cognitive assessment of the situation in which we find ourselves. The initial cognitive evaluation determines whether a stimulus reaching the brain is identified as a source of stress. If this stressor (situation) is assessed as a threat, a challenge, a loss/harm, then the basic adaptive process of 
coping is initiated. Coping is defined by Susan Folkman and Richard S. Lazarus as "cognitive and behavioural efforts to manage specific external and/or internal demands that tax or exceed the resources of the person" (Sheridan, Radmacher 1997, 9). The very process of coping with a difficult situation depends on a secondary cognitive assessment of the situation in which the person assesses what he or she can do to meet its requirements. This cognitive activity therefore relates to the ability and resources to cope with a stressor.

Richard S. Lazarus and Susan Folkman have identified two categories of coping strategies: problem focused strategies and emotionally focused strategies. Problemfocused coping is aimed at controlling the stressor (situation) in such a way as to achieve the previous goal, which requires searching for, collecting, processing and using information about the stress event, thus realistically and accurately assessing the stressor and available resources. A person's cognitive activity is therefore directed to "search" the behavioural repertoire (strategies) for those that would provide an opportunity to reduce or remove the stressful properties of the situation, i.e. solve the problem.

Emotionally focused coping in turn aims to reduce unpleasant emotional tension. To this end, intrapsychic processes are included, covering all cognitive processes that regulate emotions. This function is performed by defensive mechanisms, the set of which forms the defence system of the "I". These mechanisms are unconscious processes. Their task is to defend against fear, as well as to protect the sense of dignity of the individual, his or her high self-esteem, good self-esteem (GrzegołowskaKlarkowska 1986, 15). It is worth emphasizing that defence mechanisms are the result of the process of socialization, so they are not innate properties of the subject. Functioning in different social groups, appearing in specific cultural and institutional arrangements shapes different ways of defending against fear by distorting reality or denying it. In general, however, their action - as unrealistic forms of protection against difficult situations - is adaptive. They alleviate symptoms of stress, but do not eliminate its causes.

Coping in the context of my own research (Cywińska 2017, 225 - 231) on children at the end of early school education, i.e. 8 and 9yearsold will be considered in this article on the basis of the two categories of coping strategies indicated above. In formulating the research questions on the above topic, I was therefore guided by the coping functions (categories) selected by Richard S. Lazarus and Susan Folkman: the instrumental (task-based) function, focused on the problem and the function relating to the self-regulation of emotions. Therefore, I asked children the following questions:

Think and tell me what can be done to cope with a problem that causes fear/anxiety, anger/fury, sadness?

Think and tell me what can be done to cope with fear/anxiety, anger/fury, sadness? 
It must be noted that a considerable proportion of the children surveyed did not provide answers to questions about problem focused and emotionally focused coping strategies. Empirical research has shown that some children were not able to indicate any ways of coping in difficult situations, in stressful situations or their answers were inadequate in relation to the questions posed. The analysis of children's statements on the above questions shows that children prefer the following strategies for coping with problems and emotions. These are in order of preference:

seeking guidance and support (coping with the problem -76 answers; coping with emotions - 57 answers),

trying to forget about the problem (coping with the problem - 51 answers, coping with emotions - 53 answers),

undertaking alternative forms of activity (coping with the problem - 50 answers, coping with emotions - 51 answers),

expressive discharge of emotions (coping with the problem - 32 answers, coping with emotions - 35 answers).

Table 1. Problem-focused strategies used by children - in children's accounts

\begin{tabular}{|c|c|c|c|c|c|c|c|c|c|c|}
\hline \multirow{2}{*}{ Answers } & \multicolumn{2}{|c|}{ Girl } & \multicolumn{2}{|c|}{ Boy } & \multirow{2}{*}{$\begin{array}{l}\text { Tot } \\
\text { al } \\
\mathrm{N}\end{array}$} & \multicolumn{2}{|c|}{8 years } & \multicolumn{2}{|c|}{9 years } & \multirow{2}{*}{$\begin{array}{l}\text { Tot } \\
\text { al } \\
\mathrm{N}\end{array}$} \\
\hline & $\mathrm{N}$ & $\%$ & $\mathrm{~N}$ & $\%$ & & $\mathrm{~N}$ & $\%$ & $\mathrm{~N}$ & $\%$ & \\
\hline $\begin{array}{l}\text { Considerat } \\
\text { ion of } \\
\text { different } \\
\text { ways of } \\
\text { solving the } \\
\text { problem }\end{array}$ & 8 & $\begin{array}{l}5.44 \\
\%\end{array}$ & 4 & $\begin{array}{l}3.01 \\
\%\end{array}$ & 12 & 2 & $\begin{array}{l}3.17 \\
\%\end{array}$ & $\begin{array}{l}1 \\
0\end{array}$ & $\begin{array}{l}4.61 \\
\%\end{array}$ & 12 \\
\hline $\begin{array}{l}\text { Chi-square } \\
\text { test result }\end{array}$ & \multicolumn{5}{|c|}{$\chi^{2}=1.008990 ; \mathrm{df}=1 ; \mathrm{p}=0.031514$} & \multicolumn{5}{|c|}{$\chi^{2}=0.2446549 ; \mathrm{df}=1 ; \mathrm{p}=0.62086$} \\
\hline $\begin{array}{l}\text { Trying to } \\
\text { forget } \\
\text { about the } \\
\text { problem }\end{array}$ & $\begin{array}{l}2 \\
3\end{array}$ & $\begin{array}{l}15.65 \\
\%\end{array}$ & $\begin{array}{l}2 \\
8\end{array}$ & $\begin{array}{l}21.05 \\
\%\end{array}$ & 51 & 3 & $\begin{array}{l}4.76 \\
\%\end{array}$ & $\begin{array}{l}4 \\
8\end{array}$ & $\begin{array}{l}22.12 \\
\%\end{array}$ & 51 \\
\hline $\begin{array}{l}\text { Chi-square } \\
\text { test result }\end{array}$ & \multicolumn{5}{|c|}{$\chi^{2}=1.370040 ; \mathrm{df}=1 ; p=0.24180$} & \multicolumn{5}{|c|}{$\chi^{2}=9.875237 ; \mathrm{df}=1 ; \mathrm{p}=0.00168$} \\
\hline $\begin{array}{l}\text { Seeking } \\
\text { guidance } \\
\text { and } \\
\text { support }\end{array}$ & $\begin{array}{l}6 \\
6\end{array}$ & $\begin{array}{l}38.10 \\
\%\end{array}$ & $\begin{array}{l}2 \\
0\end{array}$ & $\begin{array}{l}15.04 \\
\%\end{array}$ & 76 & $\begin{array}{l}1 \\
8\end{array}$ & $\begin{array}{l}28.57 \\
\%\end{array}$ & $\begin{array}{l}5 \\
8\end{array}$ & $\begin{array}{l}26.73 \\
\%\end{array}$ & 76 \\
\hline $\begin{array}{l}\text { Chi-square } \\
\text { test result }\end{array}$ & \multicolumn{5}{|c|}{$\chi^{2}=18.77211 ; \mathrm{df}=1 ; \mathrm{p}=0.00001$} & \multicolumn{5}{|c|}{$\chi^{2}=.0838909 ; \mathrm{df}=1 ; p=0.77209$} \\
\hline
\end{tabular}




\begin{tabular}{|l|l|l|l|l|l|l|l|l|l|l|}
\hline $\begin{array}{l}\text { Undertaki } \\
\begin{array}{l}\text { alternative } \\
\text { forms of } \\
\text { activity }\end{array}\end{array}$ & 2 & $\begin{array}{l}14.97 \\
\%\end{array}$ & $\begin{array}{l}2 \\
8\end{array}$ & $\begin{array}{l}21.05 \\
\%\end{array}$ & 50 & $\begin{array}{l}1 \\
0\end{array}$ & $\begin{array}{l}15.87 \\
\%\end{array}$ & $\begin{array}{l}4 \\
0\end{array}$ & $\begin{array}{l}18.43 \\
\%\end{array}$ & 50 \\
\hline $\begin{array}{l}\text { Chi-square } \\
\text { test result }\end{array}$ & $\chi^{2}=1.763539 ; \mathrm{df}=1 ; \mathrm{p}=0.18418$ & \multicolumn{2}{|c|}{$\chi^{2}=.2181705 ; \mathrm{df}=1 ; \mathrm{p}=0.64044$} \\
\hline $\begin{array}{l}\text { Expressive } \\
\text { discharge } \\
\text { of } \\
\text { emotions }\end{array}$ & 1 & $\begin{array}{l}10.20 \\
\%\end{array}$ & $\begin{array}{l}1 \\
7\end{array}$ & $\begin{array}{l}12.78 \\
\%\end{array}$ & 32 & 8 & $\begin{array}{l}12.70 \\
\%\end{array}$ & $\begin{array}{l}2 \\
4\end{array}$ & $\begin{array}{l}11.06 \\
\%\end{array}$ & 32 \\
\hline $\begin{array}{l}\text { Chi-square } \\
\text { test result }\end{array}$ & $\chi^{2}=.4584041 ; \mathrm{df}=1 ; \mathrm{p}=0.49837$ & \multicolumn{2}{c|}{$\chi^{2}=0.4584041 ; \mathrm{df}=1 ; \mathrm{p}=0.49837$} \\
\hline
\end{tabular}

Source: the author - results were considered statistically significant when the calculated test probability $p$ met the inequality $p<0.05$

There is a statistical relationship $(\mathrm{p}=0.00001)$ between the sex of children (girls $38.10 \%$; boys $-15.04 \%$ ) and their preferred strategy of seeking guidance and support. The data in Table 1 show that girls were more likely than boys to seek the aforementioned support in the environment. Another statistical relationship relates to the strategy indicating attempts to forget about the problem $(p=0.00168)$, which shows that 9-year-old children $(22.12 \%)$ much more often than 8-year-old children $(4.76 \%)$ declared manifestation of this type of strategy.

Table 2. Emotion-focused strategies used by children - in children's accounts

\begin{tabular}{|c|c|c|c|c|c|c|c|c|c|c|}
\hline \multirow{2}{*}{ Answers } & \multicolumn{2}{|c|}{ Girl } & \multicolumn{2}{|c|}{ Boy } & \multirow{2}{*}{$\begin{array}{l}\text { Tot } \\
\text { al } \\
\mathrm{N}\end{array}$} & \multicolumn{2}{|c|}{8 years } & \multicolumn{2}{|c|}{9 years } & \multirow{2}{*}{$\begin{array}{l}\text { Tot } \\
\text { al } \\
\mathrm{N}\end{array}$} \\
\hline & $\mathrm{N}$ & $\%$ & $\mathrm{~N}$ & $\%$ & & $\mathrm{~N}$ & $\%$ & $\mathrm{~N}$ & $\%$ & \\
\hline $\begin{array}{l}\text { Considerat } \\
\text { ion of } \\
\text { different } \\
\text { ways to } \\
\text { solve the } \\
\text { problem }\end{array}$ & 7 & $\begin{array}{l}4.76 \\
\%\end{array}$ & 1 & $\begin{array}{l}0.75 \\
\%\end{array}$ & 8 & 3 & $\begin{array}{l}4.76 \\
\%\end{array}$ & 5 & $\begin{array}{l}2.30 \\
\%\end{array}$ & 8 \\
\hline $\begin{array}{l}\text { Chi-square } \\
\text { test result }\end{array}$ & \multicolumn{5}{|c|}{$\chi^{2}=4.045408 ; \mathrm{df}=1 ; \mathrm{p}=0.04429$} & \multicolumn{5}{|c|}{$\chi^{2}=1.062619 ; \mathrm{df}=1 ; \mathrm{p}=0.30262$} \\
\hline $\begin{array}{l}\text { Trying to } \\
\text { forget } \\
\text { about the } \\
\text { problem }\end{array}$ & $\begin{array}{l}2 \\
3\end{array}$ & $\begin{array}{l}15.65 \\
\%\end{array}$ & $\begin{array}{l}3 \\
0\end{array}$ & $\begin{array}{l}22.56 \\
\%\end{array}$ & 53 & 9 & $\begin{array}{l}14.29 \\
\%\end{array}$ & $\begin{array}{l}4 \\
4\end{array}$ & $\begin{array}{l}20.28 \\
\%\end{array}$ & 53 \\
\hline $\begin{array}{l}\text { Chi-square } \\
\text { test result }\end{array}$ & \multicolumn{5}{|c|}{$\chi^{2}=2.172691 ; \mathrm{df}=1 ; \mathrm{p}=0.14048$} & \multicolumn{5}{|c|}{$\chi^{2}=1.141889 ; \mathrm{df}=1 ; p=0.28525$} \\
\hline $\begin{array}{l}\text { Seeking } \\
\text { guidance }\end{array}$ & $\begin{array}{l}3 \\
4 \\
\end{array}$ & $\begin{array}{l}23.13 \\
\% \\
\end{array}$ & $\begin{array}{l}2 \\
3 \\
\end{array}$ & $\begin{array}{l}17.29 \\
\% \\
\end{array}$ & 57 & 9 & $\begin{array}{l}14.29 \\
\% \\
\end{array}$ & $\begin{array}{l}4 \\
8 \\
\end{array}$ & $\begin{array}{l}22.12 \\
\% \\
\end{array}$ & 57 \\
\hline
\end{tabular}




\begin{tabular}{|c|c|c|c|c|c|c|c|c|c|c|}
\hline \multicolumn{11}{|l|}{$\begin{array}{l}\text { and } \\
\text { support }\end{array}$} \\
\hline $\begin{array}{l}\text { Chi-square } \\
\text { test result }\end{array}$ & \multicolumn{5}{|c|}{$\chi^{2}=1.466833 ; d f=1 ; p=0.22585$} & \multicolumn{5}{|c|}{$\chi^{2}=1.848234 ; \mathrm{df}=1 ; \mathrm{p}=0.17399$} \\
\hline $\begin{array}{l}\text { Undertaki } \\
\text { ng } \\
\text { alternative } \\
\text { forms of } \\
\text { activity }\end{array}$ & $\begin{array}{l}3 \\
0\end{array}$ & $\begin{array}{l}20.41 \\
\%\end{array}$ & $\begin{array}{l}2 \\
1\end{array}$ & $\begin{array}{l}15.79 \\
\%\end{array}$ & 51 & $\begin{array}{l}1 \\
1\end{array}$ & $\begin{array}{l}17.46 \\
\%\end{array}$ & $\begin{array}{l}4 \\
0\end{array}$ & $\begin{array}{l}18.43 \\
\%\end{array}$ & 51 \\
\hline $\begin{array}{l}\text { Chi-square } \\
\text { test result }\end{array}$ & \multicolumn{5}{|c|}{$\chi^{2}=.9999053 ; d f=1 ; p=0.31733$} & \multicolumn{5}{|c|}{$\chi^{2}=.0310210 ; d f=1 ; p=0.86019$} \\
\hline $\begin{array}{l}\text { Expressive } \\
\text { discharge } \\
\text { of } \\
\text { emotions }\end{array}$ & $\begin{array}{l}2 \\
0\end{array}$ & $\begin{array}{l}13.61 \\
\%\end{array}$ & $\begin{array}{l}1 \\
5\end{array}$ & $\begin{array}{l}11.28 \\
\%\end{array}$ & 35 & 2 & $\begin{array}{l}3.17 \\
\%\end{array}$ & $\begin{array}{l}3 \\
3\end{array}$ & $\begin{array}{l}15.21 \\
\%\end{array}$ & 35 \\
\hline $\begin{array}{l}\text { Chi-square } \\
\text { test result }\end{array}$ & \multicolumn{5}{|c|}{$\chi^{2}=.3457624 ; \mathrm{df}=1 ; \mathrm{p}=0.55652$} & \multicolumn{5}{|c|}{$\chi^{2}=6.463316 ; d f=1 ; p=0.01101$} \\
\hline
\end{tabular}

Source: the author - results were considered statistically significant when the calculated test probability $p$ met the inequality $p<0.05$

It should be emphasised at the same time - as can be seen from Table 2 - that the result of the chi-square test is statistically significant with regard to the expressive discharge of emotions by children ( $p=0.01101)$. It turns out that age is a differentiating factor in children's preference for this strategy. The results indicate that 9-year-old children (15.21\%) use this strategy more often than 8-year-old children $(3.17 \%)$.

It follows from the empirical data presented that in order to cope with stressful situations, children first sought help from people they were in contact with, most often parents and friends. Some children's statements within this strategy are as follows: "you can talk to a colleague", "you can talk to someone", "I call my mom or dad to help me with a problem", "I hug my parents", "you can talk to your parents", "I hug my mom", "I ask my mom how to solve this", "you can talk to your mom or dad, sister or brother", "you can meet a friend", "you can talk to friends", "I'd talk to my grandmother", "you can make a plea to a loved one", "you can hug and ask your parents for help", "you can call your mom and she'll tell you what you can do", "you can confide in someone close to you", "I call a friend".

Another strategy pointed out by the children was a strategy focusing on trying to forget about the problem, which is illustrated by the following statements made by the children: "you can fall asleep", "I run into dreams, fantasy", "you can think about something nice and calm down", "I think about cool things", "you can dream", "you cannot think about it, forget about the problem", "you can go to sleep", "you can forget about the wrong thing", "you can think about something else", "you can remember something nice", "I think about good things", "I think about something funny". 
The third in the order of the children's answers was the strategy concerning their alternative forms of activity, which is illustrated by the following statements: "I play and go outside", "I draw, play board games", "I go out to the swimming pool, do sports", "I eat ice cream, read a book", "you can play with your pet", "I try to do something", "you can play with your friends", "you can read or play an instrument", "you can play with your mother or brother", "you can watch TV", "you can stroke animals", "I watch fairy tales".

The strategy of expressive discharge of emotions, in turn, is characterized by such exemplary statements as: "you can hit the pillow", "you can crumple the card", "I hit the pillow", "you can stomp on the floor", "you can scream, cry", "you can bite the pillow", "I break the crayon", "I hit the ball", "you can shout out loud", "you can tear the card", "you can crumple the newspaper".

It seems that the dominant strategy of "seeking leadership and support" which emerged in the course of the study fits into the confrontational style of coping with stress oriented towards the person/emotion (Heszen 2013,110). It shows a focus on those who could be the source of sustaining emotions; those who provide support, advice, and information about the stress situation. An important role in children's coping with stress is also played, as shown by my own research, by a style of avoiding the problem by means of suppression (a strategy that reflects attempts to forget about the problem: "I dream, fantasize", "I think about something nice, pleasant") and avoidance through distraction, reflecting the activity of doing another activity (strategy of taking alternative forms of activity: "I play with my colleagues", "I draw", "I play the instrument"). It should be added that one of the forms of avoidance through distraction is to engage in social contacts (Endler, Parker 1994, $50-60$ ) which takes into account the social aspect of coping (Folkman, Moskowitz 2004, 745 -774). Children's coping strategies in stressful situations - as shown by the study - also reflect the palliative approach(strategies) mentioned in the literature, aimed at reducing negative emotions, and the salutary approach(strategies), aimed at arousing positive emotions (e.g. dreaming of nice situations, things, listening to music), corresponding to an emotionally focused coping function (Gruszczyńska 2013, 103 119). Research on this aspect of child stress shows that children very rarely at this stage of development try to cope with difficult and/or stressful situations on their own; very rarely do they try to consider different ways of solving the problem on their own and seek help and support from people close to them. They expect to have a conversation, to find ways of solving the problem, and to seek a solution with a parent or friend.

\section{Conclusion}

The analysis of stress coping strategies for children at the end of early school education carried out on the basis of the fragment of my own research presented here leads to the global conclusion that in some children the development process has started in the indicated area: children talk, ask questions, look for, explore, wonder 
how to face difficulties. The role of adults (parents, teachers) is to give them farreaching support in this area. It is invaluable to discuss, to provoke an exchange of thoughts, to exchange views on the possibilities of solving stressful situations, difficult situations for all children. It is important to activate those who are already progressing in this area, and to stimulate those who are less reflective in this aspect.

Contemporary times show how important it is to develop, from the earliest period of an individual's life, competences in dealing with difficult situations, with stressful situations. Development of emotional intelligence, creative problem solving, the ability to establish and maintain relationships, the development of specific cognitive skills (divergent thinking, cognitive decentration), as well as psychological resilience are the basis of constructive coping with these situations. The family environment, a stable, harmoniously functioning home, as well as educational influence of preschool and early school environment play an enormous role in shaping these competences in children.

In relation to the family environment, it is extremely important that the behaviour of parents in difficult situations (conflict, stress) constitutes a constructive model for children. During childhood such processes as observation of other people's behaviour, imitation consisting in taking over external features (forms) of behaviour from another person and identification expressed in copying other people's mental states are the basis for adopting a system of behavioural norms and values from the environment (parents). By observing parents, the child not only reproduces their behaviour outwardly, but by identifying with them, more or less consciously adopts their preferred norms and values, which are expressed in their attitudes, emotions, needs, motives, opinions or various forms of action.

The author's own research cited in this text indicates that children perceive their parents' quarrels (conflicts) as the dominant stressogenic event in the family environment (Cywińska 2017, 185-208), which threatens the stability of the family and often introduces a traumatic home atmosphere, making it impossible to satisfy the child's sense of security, which is of fundamental importance for its proper development. Parental conflicts can be evidence of ongoing processes in families that take on the characteristics of a crisis of different aetiology. This leads to the conclusion that the pattern of conflict situations that children encounter in the family home does not provide them with a positive reference point for the difficult situations they will face in the future. This research $m$ ay suggest that the natural process of learning aggression (e.g. direct verbal aggression, direct physical aggression) begins in the family, and also supports the argument that aggressive children often have one or both aggressive parents who become paradigms for their own behaviour.

Since the family may not provide the conditions for children to learn to cope with difficult situations, it is very important that kindergarten and school take over this role. There are Social and Emotional Learning (SEL) programmes (Salovey, Mayer, Caruso 2004, 380-398) that address this problem in the environments described 
above; they include educational activities aimed at developing particular abilities and competences that are components of emotional intelligence. They also address issues related to solving social problems, including interpersonal conflicts. All these programmes aim to enrich the emotional and social experiences of children and young people. They also enable the development of emotional and social skills and competences. These programmes include:

The PATHS programme, designed for primary school students,

The Resolving Conflicts Creatively Programme (RCCP), designed for children and adolescents,

ECSEL's Peaceful Kids Programme for pre-school children,

Creative Response to Conflict (CRC) programme for younger school-age children,

Social Development Program K-12 run in New Heaven,

Social Development Curriculum,

Self Science programme (Matczak, Knopp 2013, 75-79; Sandy, Cochran 2005, 312332; Asher, Rose 1999, 333-366).

All of the above programmes aim to teach children and/or young people to:

recognize, name and express emotions,

represent the characteristics of feelings,

enrich their vocabulary related to emotions,

recognize the sources of feelings,

show empathy, the ability to console oneself, taking into account other people's needs, goals, aspirations,

cope with negative emotions (especially anger/rage),

understand non-verbal messages,

develop skills of constructive conflict resolution,

communicate properly and cooperate with a partner,

develop creative intelligence and creative problem solving.

Teaching children and young people constructive strategies of behaviour in conflict situations, ones that question the need to react with aggression, violence or submissiveness and passivity, is an important context for the activities proposed by the above mentioned programmes. This takes place

- in kindergarten by re-enacting different situations that are difficult for children and by exposing the negative consequences of certain behaviours in puppet shows; 
- at school by means of staging, during lessons in small groups or in front of larger audiences, various situations close to the children which are difficult, conflictual or which trigger aggression.

The programmes emphasise the need to adapt the above-mentioned areas of activity to the cognitive abilities of children and young people, to continue them in subsequent stages of their development and to implement them systematically in everyday school activities (e.g. during social-emotional skills lessons).

The programmes also emphasise the art of making and maintaining friendships to prevent social isolation - which can lead to violence and aggression - and the role of friendship in helping children and young people cope with difficult and stressful situations. Friendship is "a specific relationship between two children, characterised by mutual affection, placing the friend above other peers and a sense of sharing experiences with him/her" (Asher, Rose 1999, 339). During the course of the friendship relationship, the child's need for fun and entertainment, i.e. the desire for companionship and to spend leisure time together, is satisfied. In difficult matters the child also has the opportunity to receive anti-stress support from a friend. Children who have positive relationships with their peers can generally count on their help, whereas children who lack social support are often deprived of it (Asher, Rose 1999, 341). Friends help to manage their own difficult emotions and to develop in the child the belief that he or she is a valuable and competent person (this may be through praise or direct help), and the intimate relationship they form together provides a wonderful space to talk about their worries, fears and anxieties and to analyse together, coming up with ways out of situations that are difficult for the child. Because this relationship is so valuable in a child's life, the programmes mentioned above highlight the need to involve a "friendship specialist" in schools (Asher, Rose 1999, 358), whose task is to help children solve their problems with their peers and to develop in them competences that foster the establishment and maintenance of friendship relationships. Emotional intelligence therefore fosters satisfying interpersonal relationships and the acquisition of social support.

The results of my own research presented in Table 1 and Table 2 also show that 8and 9-year-old children very rarely attempt to solve a stressful problem on their own, or possibly attempt to seek a solution to a stressful problem. Therefore, it becomes extremely important to develop this skill in children. It should be emphasized that problem-solving skills develop with age, as Jeffrey S. Turner and Donald B. Helms point out (Turner, Helms 1999, 296). Therefore, it is important to stimulate children's skills in this area - especially in solving cognitive tasks - through specially selected educational activities. They should promote the child's effective use of specific cognitive styles to find solutions to problems. Children may represent:

the analytical style, when they examine the fine details of stimulus objects,

the superior style, when they look for common properties of objects, 
the activity-oriented style, which represents combining objects or events into groups that have some interacting properties,

the activity-placement style, which reflects classification based on shared location (Turner, Helms 1999, 297; Cywińska 2014, 187).

The research shows that younger children (aged four to six) are better at using the activity-oriented style, while older children (aged six to eleven) are better at using the superior and analytical styles. It is also worth emphasising that problem solving requires the effective use of two types of thinking: divergent and convergent. The former reflects intellectual creative abilities, which manifest themselves in the search for many different solutions to a given problem and exploring many ideas, while the latter reflects a class of processes of an analytical nature, enabling the evaluation and critical examination of the resulting ideas (Groborz, Ślifierz - Wasilewska 2003, 208 -211). Both types of thinking are necessary during problem solving, which is a multiphase process consisting of certain phases: the phase of recognising and defining the problem, the phase in which we look for different possible solutions to the problem, the phase reflecting the critical evaluation of the draft solutions, then the phase of identifying the solution that would be the most beneficial to both parties involved in the problem, the penultimate phase in which ways of practical application of the identified solution are developed, and the final phase in which the effectiveness of the identified solution is tested in practice. The second phase is based on the divergent thinking mentioned earlier, while the third and fourth phases are based on convergent thinking (Gordon 2000, 242 - 249).

Among the techniques for developing children's problem-solving skills, the technique of "brainstorming" and "paradoxical brainstorming" should be highlighted, as well as the factors of divergent thinking such as: fluency of thinking, flexibility of thinking, originality of thinking, sensitivity to problems, and elaboration. For example, let us consider two selected factors of divergent thinking: sensitivity to problems and flexibility of thinking. The first of them manifests itself in the ability to detect gaps, deficiencies, insufficiencies and imperfections that occur in different situations and people's actions. Encouraging children to describe, for example, what deficiencies a bicycle or a CD has and what difficulties are involved, we develop the aforementioned sensitivity to problems. The second factor reflecting flexibility of thinking presents a certain complexity, as it includes spontaneous flexibility and adaptive flexibility. The former consists in the production of qualitatively diverse semantic solutions, which is expressed, for example, in inventing unusual uses for various objects that help to make progress in the field in question (Szmidt 2013, 158 - 164).

In the process of teaching children how to cope with stress, creative problem solving should therefore not be neglected, in addition to the already emphasised issues focused on developing the child's emotional intelligence, which - importantly - also influences psychological well-being, understood as one's own subjectively perceived or felt well-being. 


\section{References}

[1] Asher, S.R., Rose A. J. (1999). Wspieranie społeczno- emocjonalnego przystosowania dziecka do środowiska rówieśniczego, [In:] Rozwój emocjonalny a inteligencja emocjonalna, edited by P. Salovey, D.J. Sluyter, Poznań.

[2] Calkins, S. D., Gill, K. L., Johnson, M.G., Smith, C.L. (1999). Emotional reactivity and emotion regulation strategies as predictors of social behavior with peers during toddler - hood, Social Development, 8.

[3] Cywińska, M. (2017). Stres dzieci w młodszym wieku szkolnym. Objawy, przyczyny, możliwości przeciwdziałania, Poznań.

[4] Cywińska, M. (2014). Wspieranie dzieci w procesie rozwiązywania problemów w sytuacjach konfliktu, [In:] Problemy współczesnego dziecka. Wybrane aspekty edited by M. Cywińska, Poznań.

[5] Endler, N.S., Parker, J.D. (1994). Assessment of multidimensional coping. Task, emotion and avoidance strategies, Psychological Assessment, 6.

[6] Fabes, R.A., Eisenberg, N. (1992). Young children`s coping with interpersonal anger, Child Development, 63.

[7] Folkman, S., Moskowitz, J. T. (2004). Coping: Pitfalls and promise, Annual Review of Psychology, 55.

[8] Frączek, A., Kofta, M. (1978). Frustracja i stres psychologiczny, [In:] Psychologia, edited by T. Tomaszewski, Warszawa.

[9] Frijda, N. H. (1986). The emotions. Cambridge.

[10] Gordon, T. (2000). Wychowanie bez porażek w szkole, Warszawa.

[11] Groborz, M., Ślifierz - Wasilewska S. (2003). Dwa oblicza twórczego myślenia: generowanie idei i ich ocena, [In:] Dydaktyka twórczości. Koncepcje problemy - rozwiązania, edited by K.J. Szmidt, Kraków.

[12] Gruszczyńska, E. (2013). State affect and emotion - focused coping: Examining for correlated change and causality, Anxiety, Stress and Coping, 26.

[13] Grzegołowska - Klarkowska, H. (1986). Mechanizmy obronne osobowości, Warszawa.

[14] Heszen, I. (2013). Psychologia stresu. Korzystne i niekorzystne skutki stresu życiowego, Warszawa.

[15] Heszen-Niejodek, I. (2000). Stres i radzenie sobie - główne kontrowersje, [In:] Człowiek w sytuacji stresu, edited by I. Heszen-Niejodek, Z. Ratajczak, Katowice.

[16] Heszen-Niejodek, I. (2000). Teoria stresu psychologicznego i radzenia sobie, [In:] Psychologia. Podręcznik akademicki, vol. 3, Jednostka w społeczeństwie i elementy psychologii stosowanej, edited by J. Strelau, Gdańsk.

[17] Hobfoll, S.E. (2006). Stres, kultura i społeczność. Psychologia i filozofia stresu. Gdańsk.

[18] Hobfoll, S.E. (1989). Conservation of resources. A new attempt at conceptualizing stress, American Psychologist,44. 
[19] Lazarus, R. S. (1991). Emotion and adaptation, New York.

[20] Lazarus, R.S., Folkman, S. (1984). Stress, appraisal and coping, New York.

[21] Levine, L.J., Safer, M.A. (2002). Sources of Bias in Memory for Emotions, Current Directions in Psychological Science, 11, 5.

[22] Łosiak, W. (2007). Psychologia emocji, Warszawa.

[23] Matczak, A., Knopp K.A. (2013). Znaczenie inteligencji emocjonalnej w funkcjonowaniu człowieka, Stare Kościeliska.

[24] Murphy, B., Eisenberg, N. (1997). Young children`s emotionality, regulation and social functioning and their responses when they are targets of a peer`s anger, Social Development, 6.

[25] Oniszczenko, W. (1998). Stres to brzmi groźnie, Warszawa.

[26] Salovey, P., Mayer, J.D., Caruso, D. (2004). Pozytywna psychologia inteligencji emocjonalnej, [In:] Psychologia pozytywna, edited by J. Czapiński, Warszawa.

[27] Sandy, S.V., Cochran K.M. (2005). Rozwój umiejętności rozwiązywania konfliktów u dzieci: W okresie od wieku przedszkolnego po dorastanie, [In:] Rozwiązywanie konfliktów, teoria i praktyka, edited by M. Deutsch, P.T. Coleman, Kraków.

[28] Selye, H. (1977). Stres okiełznany, Warszawa.

[29] Sheridan, Ch. L., Radmacher, S.A. (1997). Radzenie sobie w sytuacjach trudnych, Nowiny Psychologiczne, 4.

[30] Szmidt, K.J (2013). Pedagogika twórczości, Sopot.

[31] Terelak, J.F. (2001). Psychologia stresu, Bydgoszcz.

[32] Turner, J.S., Helms D.B. (1999). Rozwój człowieka, Warszawa.

[33] Witkin, G. (2000). Stres dziecięcy, Poznań. 